\section{Estimation of Manganese, Zinc and Copper in Multimineral Preparation Containing Vitamins: A Complexometric Approach}

Mohammad Anwarul Basher ${ }^{1}$, Rebecca Banoo ${ }^{2}$, Shamsul Haque ${ }^{3}$ Department of Pharmacy, Noakhali Science and Technology University ${ }^{1}$ Department of Pharmaceutical Chemistry, University of Dhaka ${ }^{2}$ Department of Pharmacy, Stamford University Bangladesh ${ }^{3}$
*Corresponding Author Mohammad Anwarul Basher Lecturer, Department of Pharmacy Noakhali Science and Technology University, Bangladesh

Contact no.: +8801726742586

E-mail: mabasher@live.com

\begin{abstract}
A simple, precise, complexometric titration method has been developed for the estimation of essential trace metals- manganese, zinc and copper, in marketed multimineral pharmaceutical dosage form containing vitamins. The selectivity of the method is accomplished by masking the minerals with suitable masking agent $(\mathrm{NaCN})$ and determining the metal ion using Complexon III (EDTA). The method having high recovery range has successfully been applied for the determination of these trace metals in presence of other minerals and vitamins. The values of different statistical parameters (e.g., standard deviation, coefficient of variation, standard error, confidence interval) were also determined, which reflect the accuracy and validity of the proposed method.
\end{abstract}

Key words: Multimineral, complexometric titration, $\mathrm{Na}_{2}$ EDTA.

\title{
INTRODUCTION
}

Manganese, zinc and copper, three very important members of the trace metals, play significant roles in the enzyme activities and a few very important structural and regulatory functions of the body (Remington. 2001). Owing to the increasing need in nutrition, there is a need for methods for determination of these metals in pharmaceutical preparations and other food products. The marketed multimineral pharmaceutical dosage form with vitamins is a preparation containing 32 active ingredients (20 minerals and 12 vitamins) where the amount of manganese, copper and zinc are $1 \mathrm{mg}, 37.04 \mathrm{mg}$ and $2 \mathrm{mg}$ respectively.

A number of methods are reported by several authors (Batsura. 1969; Cousins. 1985; Gacher et al. 1990; Hall et al. 1979; Klein et al. 1991; Knobeloch et al. 1994; Lee et al. 1989; Nriagu et al.1988; Sharrett et al. 1982; Solomon. 1985; Stein et al. 1976) for the determination of manganese, zinc and copper from different type of preparations. The British Pharmacopoeia (1988) and United States Pharmacopoeia (1985) describe methods for the determination of manganese, zinc and copper from single component preparation. The present study reports a simple and precise method having high recovery rate for the estimation of these trace metals in marketed multi-mineral pharmaceutical dosage forms containing vitamins.

\section{EXPERIMENTAL}

Samples were collected from the retail pharmacy shops in a random manner and coded $\mathrm{S} 1, \mathrm{~S} 2, \ldots$. ....S7.

\section{Preparation of sample solution}

Ten tablets from each sample were taken, weighed on an electronic balance (AA-200, Denver instrument, UK) and the average weight of each tablet was determined. The coating on the tablet was removed simply by washing under tap water, then by soaking with filter paper. Then Tablets were triturated into fine powder using mortar and pestle. Then powder equivalent to 1 tablet was taken in a $100 \mathrm{ml}$ beaker, $10 \mathrm{ml}$ of $1 \mathrm{~N}$ Hydrochloric acid was added and heated on a water bath for 5 minutes with constant stirring with a glass rod. The solution was then cooled and filtered in a vacuum filter; the residue and the beaker were washed several times, filtered and collected. 
The filtrate was taken in a $100 \mathrm{ml}$ beaker and to it $1 \mathrm{ml}$ concentrated nitric acid (Merck, specific gravity -1.52 ) and $1 \mathrm{ml}$ concentrated hydrochloric acid (Merck, specific gravity -1.19 ) were added and heated to dry on a water bath . Then $2 \mathrm{ml}$ of $33 \%$ hydrogen per oxide was added and extracted thrice with $15 \mathrm{ml}$ of ether each time. The ether layer was discarded which contains iron and the water layer was heated on a water bath till the volume was $25 \mathrm{ml}$. The solution was neutralized by adding $3 \mathrm{~N}$ sodium hydroxide. Then a few drops of acetic acid were added to make the solution acidic. To this solution 3\% ammonium oxalate was added and centrifuged at 2000 rpm for 5 minutes. Supernatant fluid was decanted in an Erlenmeyer flask. Few $\mathrm{ml}$ of ammonium oxalate was added again and centrifuged at $2000 \mathrm{rpm}$ for 10 minutes and again the supernatant was decanted as before.

\section{Estimation of Manganese}

Few crystals of ascorbic acid were added to the decanted liquid and the volume was adjusted to $100 \mathrm{ml}$ with demineralised water. $10 \mathrm{ml}$ of the solution was taken in a conical flask and 3-4 $\mathrm{ml}$ of buffer solution of $\mathrm{pH} 10$ (ammonia ammonium chloride buffer), $1 \mathrm{ml}$ of $1 \mathrm{M}$ sodium cyanide and excess quantity of $0.001 \mathrm{M}$ complexon III $\left(\mathrm{Na}_{2} \mathrm{EDTA}\right)$ was added. A blank solution was prepared by adding $3-4 \mathrm{ml}$ buffer of $\mathrm{pH} 10,1 \mathrm{ml}$ of $1 \mathrm{M} \mathrm{NaCN}$ and the same amount of complexon III as in the sample solution. Both the sample \& blank were heated to $60^{\circ} \mathrm{C}$ on a water bath. Then the excess EDTA was titrated with $0.001 \mathrm{M}$ magnesium sulfate using Eriochrome black $T$ as an indicator. Results obtained are entered in Table-1.

\section{Estimation of Zinc}

To the sample solution used earlier for manganese estimation, $1 \mathrm{ml}$ of $1 \mathrm{M}$ solution of chloral hydrate was added. Then the solution was titrated with complexon III and the amount of zinc was calculated. Results obtained are entered in Table-1.

\section{Estimation of Copper}

Then acetic acid was added until pH of the solution was 6 . Excess amount of EDTA was added and titrated against $\mathrm{MgSO}_{4}$. Again, for blank titration, in a conical flask, $3-4 \mathrm{ml}$ of buffer $\mathrm{pH} 10,1 \mathrm{ml}$ of $\mathrm{NaCN}(\mathrm{M})$ and excess amount of disodium EDTA $(0.001 \mathrm{M})$. Then the solution was titrated against $\mathrm{MgSO}_{4}(0.001 \mathrm{M})$ using Eriochrome black T as indicator. After reaching end point, $1 \mathrm{ml}$ of $1 \mathrm{M}$ chloral hydrate was added in the solution and acetic acid was added until the $\mathrm{pH}$ of the solution was 6 . Then again excess amount of EDTA was added and titrated against $\mathrm{MgSO}_{4}$. Results obtained are entered in Table-1.

\section{Recovery Experiment}

Four $100 \mathrm{ml}$ beakers were taken and labeled 1, 2, 3 and 4 . In each of them, an amount of powder equivalent to one tablet was taken and $0.0 \mathrm{mg}, 5 \mathrm{mg}, 10 \mathrm{mg}$ and $15 \mathrm{mg}$ manganese sulfate, zinc sulfate and copper sulfate were added respectively. Then the proposed method was followed to determine the amount of manganese sulfate, zinc sulfate and copper sulfate in each of the sample (Sane et al. 1982).

\section{RESULTS AND DISCUSSION}

The proposed method was successfully applied for the analysis of manganese, zinc and copper in multivitamin multi-mineral tablets (Coded $S_{1}-S_{7}$ ). All the samples assayed by the proposed method were found to meet the BP and USP requirements. Results obtained are entered in Table1. Multi-vitamin tablets containing multi minerals are sugar coated. The sugar coat was removed by washing the tablets with water. By filtering the acid solution of the tablet powder all the insoluble substances including vitamin $\mathrm{A}, \mathrm{D}, \mathrm{E}$ and $\mathrm{K}$ were eliminated. Water soluble vitamins which remain in the sample solution do not interfere with the selective complexation of manganese, zinc and copper with $\mathrm{Na}_{2}$ EDTA solution. Among the minerals present in the preparation ferrous sulfate, manganese sulfate, potassium sulfate, zinc sulfate/oxide, calcium and copper all are soluble in acid water system. The solution was made free from iron by extracting the solution several times with ether; calcium was excluded by precipitation (as calcium oxalate) and centrifugation. The final solution contains manganese, zinc, copper and potassium from which manganese and zinc were determined by selective masking of other minerals. This selectivity was obtained by the use of specific masking agent which requires no complicated reaction procedure. The concentration of EDTA solution $(0.001 \mathrm{M})$ used in this method was 50 times diluted than that stated in BP and 100 times diluted than that in USP method. 
Table 1: Estimation of manganese, zinc and copper in multivitamin multimineral preparation

\begin{tabular}{|c|c|c|c|c|c|c|c|c|c|}
\hline \multirow{2}{*}{ SL } & \multicolumn{3}{|c|}{ Manganese (mg) } & \multicolumn{3}{|c|}{ Zinc (mg) } & \multicolumn{3}{|c|}{ Copper (mg) } \\
\hline & 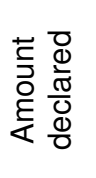 & 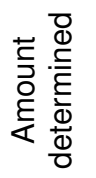 & $\begin{array}{l}\text { ठे } \\
\frac{0}{0} \\
\frac{0}{0} \\
0 \\
\circ \\
\circ\end{array}$ & 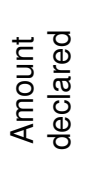 & 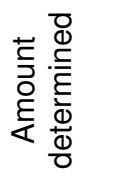 & $\begin{array}{l}\text { ò } \\
\frac{c}{0} \\
0 \\
0 \\
0 \\
0 \\
0\end{array}$ & 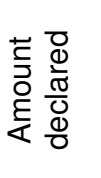 & 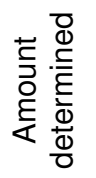 & 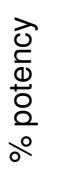 \\
\hline $\mathrm{S}_{1}$ & 1.00 & 1.10 & 110 & 37.04 & 37.04 & 100.00 & 2.00 & 1.94 & 97.0 \\
\hline $\mathrm{S}_{2}$ & 1.00 & 1.08 & 108 & 37.04 & 36.78 & 99.30 & 2.00 & 1.89 & 94.5 \\
\hline $\mathrm{S}_{3}$ & 1.00 & 1.01 & 101 & 37.04 & 37.12 & 102.00 & 2.00 & 1.99 & 99.5 \\
\hline $\mathrm{S}_{4}$ & 1.00 & 1.04 & 104 & 37.04 & 36.78 & 99.30 & 2.00 & 1.84 & 92.0 \\
\hline $\mathrm{S}_{5}$ & 1.00 & 1.01 & 101 & 37.04 & 36.72 & 99.14 & 2.00 & 2.24 & 112 \\
\hline $\mathrm{S}_{6}$ & 1.00 & 0.98 & 098 & 37.04 & 36.82 & 99.40 & 2.00 & 2.14 & 107 \\
\hline $\mathrm{S}_{7}$ & 1.00 & 1.04 & 104 & 37.04 & 36.65 & 98.95 & 2.00 & 1.89 & 94.5 \\
\hline
\end{tabular}

Selectively in EDTA titration of mixture of metals can be achieved by adding masking agent, a component that complex strongly with one of the metals, thus decreasing its conditional constant with EDTA so that this metal is not titrable. In this situation, the second metal is available for titration without influence. The masking agent- cyanide used in this method masked copper and zinc, from which manganese was determined. After the determination of $\mathrm{Mn}$, chloral hydrate was added to demask zinc, and then zinc was determined. Then solution was made acidic for the determination of copper.

From the result of recovery experiment it was found that the recovery is more than $98 \%$ for manganese (98.4\%), zinc (98.96\%) and copper (99.16\%) that is there was almost no loss even after several steps of the proposed method. Moreover more than $98 \%$ recovery proves the accuracy and reproducibility of the proposed method in addition to its simplicity (Table-2).

Table-2: Recovery experiment for manganese, zinc and copper by the proposed method

\begin{tabular}{|c|c|c|c|c|c|c|c|}
\hline Metals & $\begin{array}{l}\mathrm{SI} \\
\text { No }\end{array}$ & $\begin{array}{l}\text { Amount } \\
\text { present }\end{array}$ & $\begin{array}{c}\text { Amount } \\
\text { added }(X)\end{array}$ & $\begin{array}{c}\text { Amount } \\
\text { calculated }(\mathrm{Y})\end{array}$ & $X Y$ & $x^{2}$ & $\begin{array}{c}{ }^{*}(\%) \\
\text { recovery }\end{array}$ \\
\hline \multirow{4}{*}{$\mathrm{Mn}$} & 1 & 1.00 & 0.00 & 1.30 & 0.00 & 0.00 & \multirow{4}{*}{98.40} \\
\hline & 2 & 1.00 & 5.00 & 5.91 & 29.55 & 25.00 & \\
\hline & 3 & 1.00 & 10.00 & 11.28 & 112.8 & 100.00 & \\
\hline & 4 & 1.00 & 15.00 & 15.90 & 238.50 & 225.00 & \\
\hline \multirow{4}{*}{$\mathrm{Zn}$} & 1 & 37.04 & 0.00 & 37.12 & 0.00 & 0.00 & \multirow{4}{*}{98.96} \\
\hline & 2 & 37.04 & 5.00 & 41.73 & 208.65 & 25.00 & \\
\hline & 3 & 37.04 & 10.00 & 47.74 & 477.74 & 100.0 & \\
\hline & 4 & 37.04 & 15.00 & 51.64 & 774.15 & 225.00 & \\
\hline \multirow{4}{*}{$\mathrm{Cu}$} & 1 & 2.00 & 0.00 & 1.848 & 0.00 & 0.00 & \multirow{4}{*}{99.16} \\
\hline & 2 & 2.00 & 5.00 & 6.942 & 34.71 & 25.00 & \\
\hline & 3 & 2.00 & 10.00 & 12.03 & 120.3 & 100.00 & \\
\hline & 4 & 2.00 & 15.00 & 16.68 & 250.2 & 225.00 & \\
\hline
\end{tabular}

$$
{ }^{*}(\%) \text { Recovery }=\frac{N \sum X Y-\sum X \cdot \sum Y}{N \sum X^{2}-\sum X \cdot \sum X} x 100
$$

The results of recovery experiment had been analyzed statistically and expressed in terms of standard deviation, standard error, coefficient of variation and confirmed by the test of significance at different levels of confidence interval. The values of different statistical parameter (Table-3) 
reflect that the proposed method is accurate enough to give valid and acceptable results. For two degrees of freedom the tabulated value for $5 \%$ and $1 \%$ level of significance are 2.776 and 4.602 . All the calculated values of "t" were below this level which means the difference between the labeled potency and the determined potency by the proposed method was in closer agreement (Schwarzenbach, 1954).

Table-3: Statistical parameters of the recovery experiment of manganese, zinc and copper

\begin{tabular}{lccccccc}
\hline $\begin{array}{l}\text { Sample } \\
\text { No }\end{array}$ & $\begin{array}{c}\text { SI } \\
\text { No }\end{array}$ & $\begin{array}{c}\text { Standard } \\
\text { deviation }\end{array}$ & $\begin{array}{c}\text { Coeff of } \\
\text { variation }\end{array}$ & $\begin{array}{c}\text { Standard } \\
\text { error }\end{array}$ & $\begin{array}{c}\text { Calculated } \\
\text { "t" }\end{array}$ & \multicolumn{2}{c}{ Confidence interval } \\
$95 \%$ & $99 \%$ \\
\hline & 1 & 0.190 & 2.85 & 0.218 & 1.970 & $0.86-1.77$ & $0.567-2.07$ \\
& 2 & 0.075 & 2.149 & 0.084 & 1.866 & $5.71-6.05$ & $5.59-6.17$ \\
$\mathrm{~A}_{1}$ & 3 & 0.080 & 1.20 & 0.089 & 3.807 & $11.07-11.442$ & $10.94-11.57$ \\
$(\mathrm{Mn})$ & 4 & 0.077 & 0.822 & 0.085 & 2.691 & $15.54-16.00$ & 15.5316 .12 \\
\hline & 1 & 0.273 & 2.080 & 0.305 & 0.220 & $36.04-38.17$ & $35.30-38.87$ \\
$\mathrm{~A}_{3}$ & 2 & 0.049 & 0.321 & 0.055 & 1.762 & $43.00-43.39$ & $42.86-43.52$ \\
$(\mathrm{Zn})$ & 3 & 0.085 & 0.505 & 0.095 & 5.910 & $47.39-48.04$ & $47.22-48.35$ \\
& 4 & 0.155 & 0.853 & 0.853 & 1.680 & $51.00-52.22$ & $50.61-52.70$ \\
\hline & 1 & 0.370 & 25.06 & 0.415 & 0.86 & $1.21-2.48$ & $0.78-2.90$ \\
$\mathrm{~A}_{5}$ & 2 & 0.233 & 4.19 & 0.260 & 0.51 & $6.54-7.34$ & $6.27-7.60$ \\
$(\mathrm{Cu})$ & 3 & 0.149 & 1.54 & 0.167 & 0.40 & $11.77-12.30$ & $11.61-12.46$ \\
& 4 & 0.149 & 1.11 & 0.167 & 4.28 & $16.42-16.94$ & $16.25-17.10$ \\
\hline
\end{tabular}

\section{CONCLUSION}

The proposed method is simple and selective involving no complex technique or any critical reaction condition and has been successfully applied for the analysis of manganese, zinc and copper in pharmaceutical preparations containing various minerals and vitamins.

\section{REFERENCES}

Batsura YD. (1969) Electron-microscopic investigation of penetration of copper oxide aerosol from the lungs into the blood and internal organs. Bulletin of Experimental Biology and Medicine. 68:1175-1178.

British Pharmacopeia.(1988) Vol 1, pp 350

Cousins RJ. (1985) Absorption, transport and hepatic metabolism of copper and zinc: special reference to metallothionein and ceruloplasmin. Physiological reviews.65:238-309.

Gacheru SN, Trackman PC, Shah MA, Ogara CY, Spacciapoli P, Greenway FT, Kagan HM. (1990) Structural and catalytic properties of copper in lysysl oxidase. J Biol Chem. 190:2227.

Hall AC, Young BW, Bremner I. (1979) Intestinal metallothionein and the antagonism between copper and zinc in the rat. Journal of Inorganic Biochemistry. 11:57-66.

Klein D, Scholz P, Drasch GA, Mueller J, Summer KH. (1991) Metallothionein, copper and zinc in fetal and neonatal human liver: changes during development. Toxicology letters. 56:61-67.

Knobeloch L, Ziarnik M, Howard J, Theis B, Farmer D, Proctor M. (1994) Gastrointestinal upsets associated with ingestion of copper-containing water. Environmental Health Perspectives. 102:958-961.

Lee D, Brewer GJ, Xang Y. (1989) Treatment of Wilson's disease with zinc. Journal of laboratory and clinical medicine. 114:261-262.

Nriagu JO, Pacyna JM. (1988) Quantitative assessment of worldwide contamination of air, water and soils by trace metals. Nature. 333:134-139.

Remington. (2001) Ed. $20^{\text {th }}$. The Science and Practice of Pharmacy. 
Sane RT, Thonebare CH, Ambandeker AB, Sathe AY. (1982) Simple colorimetric determination of salbutamol sulfate in pharmaceuticals. Journal of Indian Drugs. 19(5):195-97.

Sharrett AR, Carter AP, Orheim RM, Feinleib M. (1982) Daily intake of lead, copper and zinc from drinking water: the Seattle study of trace metal exposure. Environmental research. 28:456475.

Solomon NW. (1985) Biochemical,metabolic and clinical role of copper in human nutrition. Journal of the American College of Nutrition. 4:83-105.

Stein RS, Jenkins D, Korns ME. (1976) Death after use of cupric sulfate as emetic. Journal of the American Medical Association. 235:801.

United States Pharmacopeia. (1985), pp 617 